\title{
Effects of Capital Market Development on the Economic Growth of Nigeria
}

\author{
${ }^{1}$ Udo Ginikachi Cynthia, ${ }^{2}$ Nwezeaku Nathaniel Chinedum and ${ }^{3}$ Kanu Success Ikech \\ 1,2Department of Management Technology (FMT), \\ School of Management Technology, Federal University of Technology, Owerri, Imo state. \\ Nigeria \\ ${ }^{3}$ Department of Banking and Finance, Faculty of Social and Management Sciences, Eastern \\ Palm University, Ogboko Ideato, Imo State. Nigeria
}

\begin{abstract}
This study examines the effect of capital market development on the economic growth of Nigeria using data on Real Gross Domestic Product as a proxy for economic growth while capital market variables constitute the independent variables. This includes Market Capitalization, All Share Index, Number of Listed Securities and the number of listed companies The study adopted an expost-facto research design which utilized secondary data for the period 1983 -2016. While an Augmented Dickey-Fuller unit root test was used for preliminary analysis; an Autoregressive Distributed Lag (ARDL) was used for the model estimation. .A combination of ARDL bounds test for co-integration, ARDL short and long run error correction models were used for estimation. All the tests helped to confirm the integrity of our models. Findings of the study indicate that, the Number of listed Securities and All Share Index maintained a significant relationship with economic growth in Nigeria both in the short and long runs. Based on the findings of study it was recommended that government should help to remove all impediments to stock market development in the form of tax, legal and regulatory barriers as they act as disincentives to investments in the capital market. Again, government should help to maintain policy consistency in the pursuit of growth in the Nigerian capital market. By so doing, counter developmental policies should not be allowed to crowd out the gains of capital market development and by extension on economic growth in the long run. Lastly the government should find ways and means of boosting the confidence of investors to retain their portfolio investments.
\end{abstract}

Keywords: Capital market, All share index, Market capitalization, Number of listed securities, number of listed companies

\section{Introduction}

\subsection{Background of the Study}

The capital market is a profoundly specific and coordinated financial market and indeed essential agent of economic growth and development (Odetayo and Sajuyigbe, 2012; Okoye and Nwisienyi, 2013) due to its capacity its ability to facilitate and mobilize saving and investment (Okodua and Ewetan, 2013)

Donwa and Odia, 2010). Shallu (2014) describes the capital market as a market where borrowing and lending of long term funds takes place involving both debt and equity like shares, debentures, bonds etc.

Emeh and Chigbu (2014) posit that capital market adds to financial growth through the through the specific services it performs either directly or indirectly, notable among these functions are: mobilization of savings, creation of liquidity, risk diversification, improved dissemination, acquisition of information, and enhanced incentive for corporate control 
Adeusi (2013) opines that capital market is a driver or lubricant that keeps turning the wheel of the economy to growth and development because of its imperative function of not just mobilizing long term funds and channeling them to productive investment, but also effectively allotting these assets to projects of best returns to fund owners.

Although the relationship between capital market and economic growth has been researched in the past in Nigeria, there is still a lot of left to be desired as it concerns its transmission effect to the growth of the economy and also what channels cum variables are most influencing in achieving this feat. The inconclusiveness in research findings makes a case for undertaking this study to lend empirical evidence as well as close the existing research gaps in the aspect of declining market capitalization in Nigeria.

\subsection{Problem Statement}

There is no gain saying the fact that, the rate of development at the Nigerian capital market has not been able to effectively mobilize capital for the development of other vital sectors of the Nigerian economy. The major reason adduced for this seeming neglect is due to the predominant role the oil sector is playing as the major foreign exchange earner in the country.

The year 2016 witnessed a plunge in oil prices and that of stock market, which remained indelible in the minds of investors on the Nigerian Stock Exchange (NSE), just as it was in the 2008 global financial meltdown, which stemmed from the fact that, the nation's stock market for the period under review experienced a major setback to the tune of over N1trillion drop in market capitalization. The fall in oil prices also led to the withdrawal of lots of investors and listed firms on the stock market. The share index ratios were not spared either. This was due majorly to the endogenous factors characteristic of the Nigerian financial system. A lot of investments ended up sustaining substantial losses. These helped to dampen the investor's confidence and eventually led to a decline in growth of the capital market as well as the rate of economic growth in Nigeria.

At this juncture, there are some are pertinent questions that need be asked: - following the plunge of the Nigerian capital market in 2016, what efforts are the government and concerned individuals making to bring back the lost glory of the capital market? What efforts are being made to attract foreign investors into Nigeria and thus, sustain their confidence in the long run given their previous experiences with the stock market? What is the government doing to raise the level of growth in the capital market to complement other sectors of the economy to achieving economic growth? Is the market being supplied with enough securities for trading as depicted by the All share index, market capitalization and the number of participants in the Nigerian capital market?

Lastly, ignorance on the part of the investing public is not helping matters. Most of the investors are conservative. They still are still aligned to the practice of buy and hold stock. They seem to be contented with the dividends they will receive therein, but the truth remains that, that is not the main essence of trading in stocks or participating in stocks trading at the stock market. Shares need to be traded upon regularly for the market to advance and to function effectively and efficiently. These and many more are the problems that this study intends to proffer solutions to.

Thus, this study is set to ascertain the effects of capital market development on the economic growth of Nigeria.

\subsection{Objectives of the Study}

The broad objective of this study is to examine the effect of capital market development on the economic growth of Nigeria. The specific objectives are to determine the effect of:

i. Market Capitalization on the economic growth of Nigeria;

ii. Listed number of securities on the capital market on the economic growth of Nigeria;

iii. The All share index on the economic growth of Nigeria.

iv. Listed number of companies on the capital market on the economic growth of Nigeria.

\subsection{Research Questions}

In line with the above objectives, this research work aims at answering the following questions:

i. To what extent has Market capitalization impacted on the economic growth in Nigeria? 
ii. To what extent has the Number of listed securities impacted on the economic growth of Nigeria?

iii. To what extent has the all share index impacted on the economic growth of Nigeria?

iv. To what extent has the total Number of listed companies on the stock market impacted on the economic growth of Nigeria?

\subsection{Hypotheses of the Study:}

HO$_{1}$ : Market Capitalization at the Nigerian stock market does not have a significant effect on her level of economic growth.

$\mathbf{H O}_{2}$ : The Number of listed securities on the Nigerian capital market does not have a significant effect on the economic growth of Nigeria.

$\mathbf{H O}_{3}$ : The All share index of the Nigerian capital market does not have a significant effect on the economic growth of Nigeria

$\mathbf{H O}_{4}$ The Number of companies listed on the Nigerian capital market does not have a significant effect on the economic growth of Nigeria

\subsection{Significance of the Study.}

This study will be of immense benefit to Policy Makers It will enable them to fashion out good and effective policies that could help move the capital market forward. It will also be of assistance to private and corporate investors.. It will enable them understand the dynamic surrounding the operations of the market. This study will offer to other researchers an ample opportunity to critique the work and, thus expand on the existing body of knowledge on subject matter. Lastly, this study could also help to educate the general public on the important role the capital market can play in the economic growth of the nation.

\section{Conceptual Framework}

\subsubsection{An Overview of the Nigerian Capital Market.}

The capital market consists of institution and mechanisms through which economic units desirous to invest their surplus fund, interact directly or through financial intermediaries with those who wish to procure funds for their businesses. The Securities and Exchange Commission (SEC) is a major regulator in charge of the Nigerian stock market while the Nigerian Stock Exchange (NSE) supervises the operations of the formal quoted market (as a self- regulatory organization).

However, the Nigerian financial markets are encountering difficulties such as poor infrastructural facilities, low level of public awareness as to the benefits derivable from the operation of the capital market, inadequacy of supply of securities, stringent stock exchange listing requirements limiting mostly the smaller companies, illiquid market and unfavorable government policies (Taiwo, 2016).

\subsubsection{Structure of the Nigerian Capital Market}

The capital market operations are organized into three broad categories: the primary, secondary and derivatives markets.

The Primary Market: it is answerable for the issue of new offers through the stock exchange or by private placement. Their activities are directed through the following strategies: offer for subscription, offer for sale, right issue, private placing and listing by introduction (Taiwo, 2016).

The Secondary Market: also referred to as the stock market, it provides the forum for capital market activities (trading in stock and shares, bonds, debentures and other long-term securities) and is usually accessible to all category of investors - small or big, government institution or individuals. The major participant in the Nigerian capital market includes development banks, private firms, the treasury and the CBN while the minor ones includes commercial and merchant banks, individuals, states and local governments. The secondary market is an important segment of the capital market because it provides an avenue for investors to convert their securities to cash and allow those wishing to buy additional existing securities to do so. (Alaka, 2016).

The Derivatives Market: This is the market that trades, not in the issued securities, but on the right to title on the underlying security or on the basis of the future title to the security. The 
derivatives market in Nigeria is still in its infancy and the only derivative presently being actively traded on the Nigerian Stock Exchange is right offer issue options.

\subsubsection{Method of Trading in the Secondary Market. The Call over System}

Stock brokers gather on the same floor of the stock exchange at a given period of trade on the listed securities. The listed securities are then read out aloud, one after the other by a presiding official of the stock exchange called the call over chairman. As each security is being read out, the stock brokers who had orders to buy or sell indicate interest at the price at which they were willing to strike a deal. Thereafter, bargain slips will be exchanged after the transactions had been authenticated by the stock exchange. (Alaka, 2016)

\section{The Auction Market}

The market does not exist in Nigeria, but in the more developed markets such as U.K, U.S.A, and Japan.

\section{The Automated Screen-Based Training System}

The Automated-Screen-Based Training System (ATS) is a process which allows trading to be done electronically such that orders to buy and sell are traded electronically. Nigerian capital market is presently operating an Automated Trading System (ATS).

\subsubsection{The Central Securities and Clearing System as a Subsidiary Of Nse}

Central securities clearing system (CSCS) was established on $14^{\text {th }}$ April, 1997 . It serves as a central depositing for all shares certificates of quoted securities including new issues. The CSCS operates an automated clearing and settlement system, i.e the transfers of stock possession from one shareholder to another and the transfer of sales proceeds from the buying shareholder to the selling shareholder. The transfer of shares is presently done on a T+3 (Trading day + three working days) time frames under the automated CSCS while transactions are executed on the basis of delivery versus payment. Since its introduction in 1997, it has diminished instances of fraud perpetuated by capital market operator's especially stock brokers. It also provides clearing settlement and custodian services for local and foreign investments. CSCS brought the Nigerian stock market at par with what is obtained from other developed countries.

\subsubsection{Benefits of Listing on the Nigerian Stock Exchange To the Government}

a. Source of cheap financing for infrastructure projects.

b. Better valuation of corporate taxes due to disclosures

c. Social stability; quoted firms are not susceptible to attacks during communal disturbance due to common ownership become paramount.

\section{To the Company}

a. Access to capital at minimal cost

b. Transparency and credibility in operation

c. Marketing of shares

d. Free publicity and advertisement (local/international)

e. Eternal life (perpetual operation)

f. Ease of valuation of shares - As determined from trading

g. Code of corporate governance as a corrective tool

h. Capital market - discipline (disclosure ensures high ethical standards)

i. $\quad$ Risk sharing

j. Greater visibility: The possibility of being included on a major performance index e.g.,

the NSE - 30, translating into greater liquidity.

k. Qualification of investment by pension funds administrators.

\section{To the Society -}

There is an efficient flow of capital, generation of employment, reduction in crime and an improvement in the standard of living occasioned by production of high quality goods and services.

\section{To the Investor}

a. Provide exit rout for existing owners 
b. Avenue to share in the fortunes of viable companies

c. Outlet to reduce current consumption promotes savings

d. Avenue for incorporating securities in a portfolio as part of the financial planning process.

e. Avenue for safe guarding wealth/security of investment

f. Shelter to the impact of inflation.

\subsubsection{Characteristics of the Nigerian Capital Market}

Stock market development can be categorized using three main characteristics. This includes the traditional, institutional and asset pricing. These are briefly discussed below:

1. Traditional Characteristics: The traditional characteristics are concerned with basic growth measures of stock market. These measures include number of listed companied and market capitalization.

2 Institutional Characteristics: The institutional characteristics measures are the regulatory and legal job that may influence functioning of the market, information divulgence and transparency prerequisites as well as market barriers and trading costs

3. Asset Pricing Characteristics: This deals with the efficiency of the asset pricing process in the securities market. The major yardstick for measuring efficiency in terms of market prices is the informational content inherent in such prices.

The Securities and Exchange Commission (SEC).

This is the Apex Regulatory institution of the Nigeria capital market. It is a statutory body administered by the federal ministry of finance.

\subsubsection{Measurement of Growth in the Nigerian Capital Market.}

The growth of Nigeria's capital market can be ascertained through the following measures

\section{Gross Capital Formation:}

The stock of capital formation in a progressive economy should reflect the growth and development in the capital market especially, in a cordial helpful environment. There seems to be a consensus among development experts that the level of domestic capital formation in Nigeria is low due to low degree of investment arising from inadequate capital asset. Market Capitalization also known as market value is the share value times the quantity of share outstanding.

All Share Index: This is a quick measure to pass judgment on the overall course of the market and the extent of its development

\section{Stocks Traded (Total Value)}

This alludes to the total value of share traded during a particular timeframe.

\section{Total New Issue}

This term doesn't necessarily allude to newly issued stocks, although initial public offerings are the most commonly known new issues. Securities that can be newly issued include both debt and equity. A company makes a new issue through guarantors who have the duty to place the offering with individual and institutional investors

\section{Listed Domestic Companies}

Listed domestic companies are the domestically incorporated companies listed on the country's stock exchange at the end of the year..

\section{Total Listed Equities}

This is the total amount of preferred stock equity added to the amount of common stock equity.

\section{Government Stock (bonds)}

It is a bond issued by a national government, generally with a promise to make a periodic interest payment and to repay the face value on the maturity date.

\subsubsection{Functions of the Nigerian Capital Market.}

There are various functions performed by the Nigerian capital market that are helping to support the nation's economy. The Nigerian capital market serves as a link between Investors and Savers. It encourages Savings an investment.It also promotes economic growth and stabilizes the price of securities 


\subsubsection{Impact of Capital Market on Economic Growth in Nigeria.}

The capital market has impacted on economic growth and advancement of Nigeria through the following means:

I) It is encouraging the inflow of foreign capital when foreign companies or investors invest in domestic securities.

ii) It is helping to diminish over reliance of the corporate sector on short term financing for long term projects and also gives opportunities to government to finance projects aimed at providing essential amenities for financial turn of events.

iii) The stock market has impacted decidedly by providing avenue for the marketing of shares and other securities in order to raise new asset for expansion of operations leading to increase production/yield.

iv) The stock market is helping to give means of allocating the nations real and financial assets between various sectors, industries and companies

\subsubsection{Challenges of the Nigerian Capital Market.}

The Nigerian Capital Market is still faced with some challenges. This includes investors apathy. Investors are still terrified to raise money in the capital market. There is still this challenge of misappropriation of assets and extravagant uses, corruption, insufficient information about the market, lack of active control and regulation on the part of the SEC, tardy growth of securities market, postponement in the provision of share certificates, issue of manual call-over, twofold taxation, small size of the market, and issue of macroeconomic volatility

\subsubsection{Shortcomings and Problems of the Nigerian Stock Market}

The Nigerian capital market has its own share of short comings and problems. This includes:

1. Unavailability of valid Information as they come forth.

2. Lack of Functioning Research Department:

3. Ignorance:

4. Inadequate Supply of securities:

5. Market Illiquidity:

6. Dominance in governments Participation

\subsubsection{The Nigerian Capital Market Reforms.}

\subsubsection{The Nigerian Capital Market Reforms.}

Financial reforms and attendant policy prescriptions are aged long phenomena. They represent the different changes and policies adjustments and overhaul that are directed at the art , practice and exercises of financial institutions and market overtime in response to nominal need for operational improvement and growth of both the institutions and economy as a whole.. They could be internal or external in nature, reflecting critical comprehensive amendment, restructuring and/or additions to the existing body of laws, guidelines and policies

In Nigeria, the capacity of the financial sub-sector to assume its part has been intermittently penetrated by its weakness to methodical misery and large scale monetary instability and policy fine tuning inevitability (Kama, 2006). Thus, the financial reforms were centered on further liberalization of banking business; guaranteeing contest and security of the framework and proactively situating their interrelation with the capital market to support financial intermediation with the desire to fill in as an impetus to economic development.

\subsection{Theoretical Framework}

The stock market is being guided by a set of rules and standards to make it work. No one rule is a master cap that fits it all situations. Its usage is a function of the ensuing scenario. Some of the basic theoretical frameworks guiding the operations of the Nigerian capital market are briefly highlighted below:

i) Efficient Market Theory: It states that assets prices fully reflect all available information. There are three variants of the hypothesis: They are the "weak", "semi-strong", and "strong" form. The weak form of the efficient market hypothesis claims that trading information of traded assets is already incorporated in prices. If weak form efficiently holds then technical analysis cannot be used to generate superior returns. The semi-strong form of the efficient market hypothesis is of the opinion that prices incorporate all publicly available information The strong form of the efficient market hypothesis claims that prices incorporate all public and non-public (insider) information, and therefore even insiders cannot expect to earn superior returns when they trade assets of which they have inside information. 
ii) Capital Assets Pricing Theory: The CAPM describes the relationship between systematic risk and expected return for assets, particularly stocks. CAPM is widely used throughout finance for pricing risky securities and generating expected returns for assets given the risk of those assets and cost of capital

iii) Arbitrage Pricing Theory: This is a multi-factor asset pricing model based on the idea that an asset's return can be predicted using the linear relationship between the assets expected return and a number of macroeconomic variables that capture systematic risk. It is a useful tool for analyzing portfolios from a value investing perspective in order to identify securities that may be temporarily mispriced.

iv) Modern Portfolio Theory: The theory is set to finding a balance between maximizing an investor's return and minimizing his risk. The objective is to select investments in such as way as to diversify ones risks while not reducing the expected return. While it does not replace the role of an informed investor, it can provide a powerful tool to complement an actively managed portfolio.

\subsection{Empirical Review}

There have been studies on the relationship between stock market operations and economic growth. Some of them are briefly reviewed below. We intend to review only the relatively recent studies and strictly from the Nigerian perspective.

Araoye, Ajayi and Aruwaji (2018) examined the impact of the Nigerian stock market development on the economic growth of Nigeria for the period 1985 to 2014. Results of their study suggested that the stock market was significant in determining economic growth in Nigeria. They recommended that policy makers should ensure improvement in the market capitalization, by encouraging foreign direct investment participation into the market.

Taiwo, Adedayo and Evawere (2016) examined the contributions of capital market to the economic growth of Nigeria. The outcome of study indicated that market capitalization rate, total value of listed securities, labor force participation rate, accumulated savings and capital formation are significant macroeconomic determinants of economic growth in Nigeria. The study recommended that, for the capital market to realizes its full potentials, its environment must be enabled to promote and encourage investment opportunities for both local and international investors

Okoye, Modebe, Taiwo and Okorie (2016) investigated the connection between capital market advancement and financial growth for the period 1981-2014. Employing the econometric methodology of the vector mistake revision model, their examination showed that in the shortrun, market capitalization proportion and turnover proportion have significant negative impact on aggregate public yield (GDP). Result of their examination additionally showed beneficial outcome of significant worth exchanged proportion just as negative impact of swelling rate on GDP though not significant. Their long-run gauge showed that every one of the exogenous factors contrarily affect GDP and that changes in market capitalization proportion, esteem exchanged proportion and turnover proportion produce more than proportionate changes in GDP. Their investigation set up that financial exchange improvement establishes a significant determinant of monetary growth in Nigeria.

Ogunleye (2015) analyzed the effect of securities exchange advancement on monetary growth in Nigeria for the period 1970 and 2008. The Cointegration Analysis and Error Correlation Mechanism were embraced as the estimating strategies to check the presence of long-run connection between securities exchange improvement and monetary growth. The exact outcomes uncovered that there is presence of long-run connection between financial exchange improvement and monetary growth in Nigeria. In view of the findings of study government, should address the shortage of venture assets through powerful policy estimates that upgrade the exhibition of securities exchange in Nigeria and to reestablish certainty of the financial backers.

Taiwo (2015) contemplated the commitment of capital market to the growth of Nigeria's economy. A blunder amendment model was assessed for monetary growth in Nigeria, using Vector Error Correction methods on a yearly time arrangement information spanning from 1981 to 2014. The result of study uncovers that market capitalization rate, all out worth of recorded protections, workforce support rate, gathered savings and capital arrangement are significant 
macroeconomic determinants variables of monetary growth in Nigeria. It was then suggested that, for the capital market to understands its true abilities, its current circumstance should be empowered to advance and encourage speculation openings for both neighborhood and global financial backers,

Enekwe (2014) did an examination on the impact of capital market in the financial growth in Nigeria for the period 1981-2012. GDP was picked as the intermediary for monetary growth while the capital market factors considered incorporates: Market capitalization, Number of recorded protections and all out worth of protections exchanged. The findings of study show that financial growth was significantly impacted simply by market capitalization. Exercises of the securities exchange might but rather have impacted the economy expected. It was therefore suggested that the regulatory specialists ought to acquaint ICT polices with encourage more organizations to get to their reconnaissance to check sharp practices which sabotage the market integrity and disintegrate financial backers certainty

Atoyebi Kehinde (2013) investigated the effect of capital market on financial growth in Nigeria using yearly information from 1981 to 2010. A normal least square test was utilized to confirm the measurable significance of the factors utilized and vector auto regression method to decide the long run relationship inside the factors of study. Exact investigations uncovered that two factors are genuinely significant at $10 \%$ and these factors are market file and market capitalization. It was prescribes that there is need to reestablish certainty to the market by regulatory specialists through ensuring transparency and reasonable trading in the stock exchange.

\subsection{Gap in the Study}

Although the relationship between capital market and economic growth has been researched in the past in Nigeria, there seems to be a gap in the level of aggregation and the choice of proxies on subject matter. This study seeks to close this gap by utilizing real gross domestic product (RGDP) as the proxy for economic growth. This will paint a true picture of real growth that is devoid of the effects of inflation. It is hoped that this will produce a more robust picture of economic growth in Nigeria occasioned by developments in the capital market.

\section{Methodology}

An ex-post facto research design was adopted in this study. The Autoregressive Distributed Lag (ARDL) was used for the model estimation on a time-series data. Real Gross Domestic Product is taken as a proxy for economic growth while capital market variables constitute the independent variables. This includes Market Capitalization, All Share Index, Number of Listed Securities and the number of listed companies. This is capture in the model below:

GDP $=f(M C A P, A S I, N L S, N C L)$

Transforming the data into a log form, the econometric model becomes;

$\log R G D P=\beta 0+\beta_{1} \log M C A P+\beta_{2} \log A S I+\beta_{3} \log N L S+\beta_{4} \log N C L+U------(i i)$

Where:

RGDP = Real Gross Domestic product; a proxy for economic growth in Nigeria

MCAP = Market capitalization

ASI $=$ All Share Index

NLS $=$ Number of Listed Securities

$\mathrm{NCL}=$ Number of Companies Listed

$\mathrm{U}=$ white noise to cater for unstable economic climate, policy conflicts, corruption and policy changes due to changes in government over the years.

\subsection{Explanation / Justification of the Chosen Variables.}

In this study we intend to use one (1) dependent and 4 four independent variables to ascertain relationships.

\section{Real Gross domestic Product}

This that been adjusted for inflationary effects. It shows the true picture of gross domestic product as a measure of economic growth and not the illusion of growth.

\section{Market Capitalization:}

This refers to the total value of a company's share of stock. It is calculated by multiplying the price of a stock by its total number of outstanding shares. Market capitalization allows investors to understand the relative size of one company versus another. Market capitalization measures 
what a company is worth on the open market as well as the market perception of its future prospects, because it reflects what investors are willing to pay for its stock. Any exercise of warrants on a company's stock will increase the number of outstanding shares, thereby diluting its existing value.

\section{Stock Market Index:}

This is a measure of a section of the stock market. It is computed from the prices of selected stocks (typically a weighted average). It is a tool used by investors and financial managers to describe the market and to compare the return on specific investments. Consumer prices drops when stock prices decreases. When GDP rises above consensus or expectations of GDP rise, corporate earnings increase, which makes it bullish for stocks. The inverse happens when GDP falls lower than consensus or expectation of GDP decline.

\section{Number of Listed Securities:}

These are investments traded on secondary market. The most well-known examples include stocks and bounds. Securities allow you to own the underlying asset without taking possession. Securities make market more efficient.

\subsection{Expected or Apriori Expectations}

This is hinged on the theoretical linkage about the signs and magnitude of the parameters of the specified functions. They are determined by the principles of financial and economic theory guiding the relationship among the variables under study. It is expected that $b_{1}>0, b_{2}>0, b_{3}>0$ and $b_{4}>0$. The expected positive signs rest on the theoretical postulation that the above variables have a direct and positive effect on economic growth of Nigeria in the long run.

\section{Data Estimation}

\section{Preliminary Tests}

ARDL indicates that the dominant lag length is 2 ; hence the lag of 2 is used in data estimation and analysis.

Table 1: Descriptive statistics

\begin{tabular}{|l|c|c|c|c|c|}
\hline & LASI & LMCAP & LNCL & LNLS & LRGDP \\
\hline Mean & 3.543698 & 2.606928 & 1.980193 & 2.555558 & 4.468491 \\
\hline Median & 3.876841 & 2.575670 & 2.265982 & 2.574641 & 4.362912 \\
\hline Maximum & 5.019650 & 4.280520 & 2.332438 & 4.538502 & 4.881142 \\
\hline Minimum & 0.000000 & 0.740363 & 0.000000 & 0.000000 & 4.183060 \\
\hline Std. Dev. & 1.214585 & 1.257997 & 0.738991 & 1.286148 & 0.225204 \\
\hline Skewness & -1.476266 & -0.129724 & -2.312885 & -0.361920 & 0.530272 \\
\hline Kurtosis & 4.938451 & 1.558538 & 6.461662 & 2.022982 & 1.735057 \\
\hline Jarque-Bera & 17.67297 & 3.038930 & 47.28955 & 2.094554 & 3.860181 \\
\hline Probability & 0.000145 & 0.218829 & 0.000000 & 0.350892 & 0.145135 \\
\hline Sum & 120.4857 & 88.63555 & 67.32655 & 86.88897 & 151.9287 \\
\hline Sum Sq. Dev. & 48.68211 & 52.22439 & 18.02155 & 54.58785 & 1.673654 \\
\hline Observations & 34 & 34 & 34 & 34 & 34 \\
\hline
\end{tabular}

Source: E-views 10 Regression output

From table above, it could be seen that LASI( Log of All share index) and LNCL ( Log of the number of listed companies) and Market capitalization (MCAP) have probability values less than 0.05; while LMCAP ( log of market capitalization), LNLS( log of number of listed securities) and LRGDP ( log of real gross domestic product) had probability values greater than 0.05 . The data is negatively skewed and asymmetrical about its mean. Based on the above observations it can be inferred that the data is not normally distributed. This can be ascertained from the normality test below: 
Udo Ginikachi Cynthia, Nwezeaku Nathaniel Chinedum, Kanu Success Ikechi

Effects of Capital Market Development on the Economic Growth of Nigeria

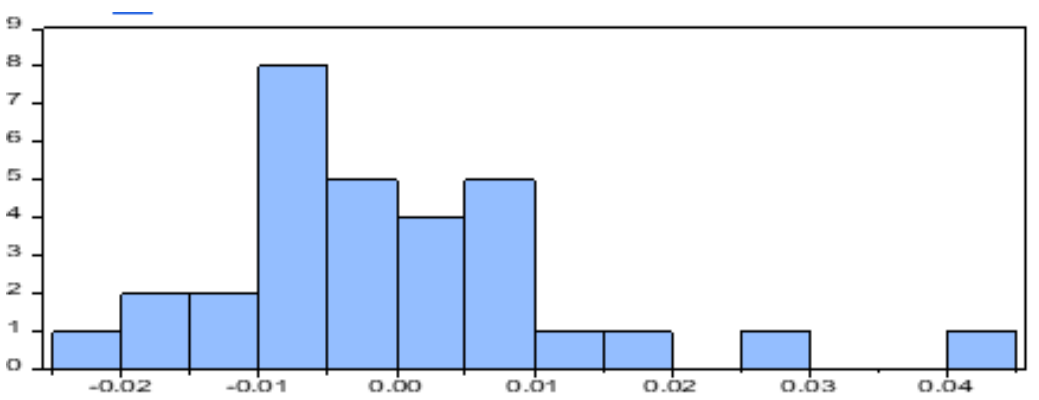

\begin{tabular}{|lr|}
\hline \multicolumn{2}{|l|}{ Series: Residuals } \\
Sample 1986 2016 \\
Observations 31 \\
Obean & $2.03 e-15$ \\
Median & 0.002217 \\
Maximum & 0.041417 \\
Minimum & 0.020501 \\
Std. Dev. & 0.012649 \\
Skewness & 1.212298 \\
Kurtosis & 5.233791 \\
& \\
Jarque-Bera & 14.03846 \\
Probability & 0.000895 \\
\hline
\end{tabular}

Figure 2: Normality Test

Source: E-views 10 Regression output

The above test revealed that the jarque-Bera coefficient is 14.03846 . It is insignificant at $5 \%$ level of significance; hence validating our earlier decision that the data is not normally distributed.

Table5: Correlation

\begin{tabular}{|c|c|c|c|c|c|}
\hline & LASI & LMCAP & LNCL & LNLS & LRGDP \\
\hline LASI & 1 & 0.8776 & 0.8039 & 0.9408 & 0.7393 \\
\hline LMCAP & 0.8776 & 1 & 0.6069 & 0.9836 & 0.9356 \\
\hline LNCL & 0.8039 & 0.6069 & 1 & 0.6855 & 0.4215 \\
\hline LNLS & 0.9408 & 0.9836 & 0.6855 & 1 & 0.9103 \\
\hline LRGDP & 0.7393 & 0.9356 & 0.4215 & 0.9103 & 1 \\
\hline
\end{tabular}

Source: E-views 10 Regression output

From the above correlation matrix, it can be seen that LASI has a strong and positive correlation with LMCAP, LNCL, LNLS and LRGDP. The same was true when LMCAP was correlated with LASI, LNCL, LNLS and LRGDP respectively. Again, this was found to be true when LNCL was correlated with LASI, LMCAP, LNCL, but showed a poor correlation with LRGDP.

LNLS also produced a positive and strong correlation when correlated with LASI, LMCAP, LNCL and LRGDP respectively. Finally, LRGDP produced a positive and strong correlation with LASI, LMCAP and LNLS respectively, but showed a weak correlation with LNCL.

The unit Root Test was carried out using the Augmented Dickey-Fuller and the summary is shown below:

Table 6: Augmented Dickey-Fuller Unit Root Test

\begin{tabular}{|l|l|l|l|l|l|l|}
\hline Variable & T-stat & $\begin{array}{l}\text { Critical } \\
\text { value at 1\% }\end{array}$ & $\begin{array}{l}\text { Critical } \\
\text { value at 5\% }\end{array}$ & $\begin{array}{l}\text { Critical } \\
\text { value at 10\% }\end{array}$ & $\begin{array}{l}\text { Order of } \\
\text { integration }\end{array}$ & $\begin{array}{l}\text { Level of } \\
\text { Significance }\end{array}$ \\
\hline LASI & -3.40 & -3.64 & -2.95 & -2.61 & $1(0))$ & significant \\
\hline LMCAP & -3.14 & -3.65 & -2.95 & -2.61 & $1(1)$ & same \\
\hline LNCL & -2.97 & -3.65 & -2.95 & -2.61 & $1(0)$ & same \\
\hline LRGDP & -4.55 & -3.65 & -2.95 & -2.61 & $1(1)$ & same \\
\hline LNLS & -1.31 & -3.66 & -2.96 & -2.61 & $1(1)$ & same \\
\hline
\end{tabular}

Source: Culled from the output of E-views statistical package version $10 .$.

From the above test, LASI and LNCL achieved stationarity at level while, LRGDP, LNLS and LMCAP were stationary at first difference. Owing to the mixed order of stationarity, the ARDL model of estimation was adopted as the appropriate technique for model estimation and analysis.

Table 7: ARDL bounds test for co-integration 
Udo Ginikachi Cynthia, Nwezeaku Nathaniel Chinedum, Kanu Success Ikechi

Effects of Capital Market Development on the Economic Growth of Nigeria

\begin{tabular}{lcccr} 
F-Bounds Test & & \multicolumn{3}{c}{ Null Hypothesis: No levels relationship } \\
\hline \hline Test Statistic & Value & Sig. & l(0) & !(1) \\
\hline \hline & & & & \\
F-statistic & 3.74 & $10 \%$ & 2.2 & 3.09 \\
k & 4 & $5 \%$ & 2.56 & 3.49 \\
& & $2.5 \%$ & 2.88 & 3.87 \\
& & $1 \%$ & 3.29 & 4.37 \\
\hline \hline
\end{tabular}

The above table shows that, there exist the presence of a long run relationship in the model since the F-statistic has a value greater than the $\mathrm{I}(0)$ and $\mathrm{I}(1)$ bounds respectively at $5 \%$ level of significance.

Table 8: ARDL Dynamic short run error correction model

\begin{tabular}{|c|c|c|c|c|}
\hline Variable & Coefficient & Std. Error & t-Statistic & Prob. \\
\hline D(LASI) & -0.530247 & 0.096508 & -5.494317 & 0.0001 \\
\hline $\mathrm{D}(\underline{\text { LASI }}(-1))$ & -0.021340 & 0.037809 & -0.564410 & 0.5821 \\
\hline $\mathrm{D}(\underline{\mathrm{LASI}}(-2))$ & 0.405018 & 0.112821 & 3.589931 & 0.0033 \\
\hline $\mathrm{D}(\mathrm{LMCAP})$ & -0.027802 & 0.026150 & -1.063196 & 0.3070 \\
\hline $\mathrm{D}(\underline{\mathrm{LMCAP}}(-1))$ & -0.090047 & 0.080965 & -1.112173 & 0.2862 \\
\hline $\mathrm{D}(\stackrel{\mathrm{LMCAP}}{\overrightarrow{\mathrm{L}}(-2))}$ & -0.083653 & 0.086326 & -0.969033 & 0.3502 \\
\hline$\overline{\mathrm{D}(\mathrm{LNCL})}$ & -0.364445 & 0.090816 & -4.012997 & 0.0015 \\
\hline $\mathrm{D}(\underline{\mathrm{LNCL}}(-1))$ & -0.046924 & 0.009944 & -4.718694 & 0.0004 \\
\hline $\mathrm{D}(\mathrm{\operatorname {LNCL }}(-2))$ & -0.015284 & 0.010194 & -1.499376 & 0.1577 \\
\hline D(LNLS) & 0.626578 & 0.102639 & 6.104652 & 0.0000 \\
\hline $\mathrm{D}(\underline{\operatorname{LNLS}} \mathrm{S}-1))$ & 0.102064 & 0.112089 & 0.910561 & 0.3791 \\
\hline $\mathrm{D}(\underline{\operatorname{LNLS}}(-2))$ & -0.185747 & 0.118188 & -1.571624 & 0.1401 \\
\hline CointEg(-1)* & -0.730926 & 0.151793 & -4.815276 & 0.0003 \\
\hline
\end{tabular}

Source 2: Restricted Constant and No Trend

\subsection{Short Run Analysis:}

LNCL: has a negative coefficient of -0.364445 .This implies that a unit increase in LNCL will negatively affect LRGDP to the tune of $3.6 \%$. It is statistically significant at $5 \%$ level of significance.

LASI: has a negative coefficient of -0.530247 .This implies that a unit increase in LNCL will negatively affect LRGDP to the tune of $5.3 \%$. It is statistically significant at $5 \%$ level of significance.

LMCAP: has a negative coefficient of -0.027802 . This implies that a unit increase in LMCAP will negatively affect LRGDP to the tune of $2.7 \%$.. It is statistically insignificant at $5 \%$ level of significance.

LNLS: has a positive coefficient of 0.626578 .This implies that a unit increase in LNLS will negatively affect LRGDP to the tune of $62.6 \%$. It is statistically insignificant at $5 \%$ level of significance.

The Error correction coefficient is negative at $(-0.730926)$ and significant at $5 \%$ level of significance. It satisfies the conditions for error correction. This means that the disequilibrium in the short run will be adjusted in the long run at the rate of $73 \%$ annually and will take less than 2 years to complete the adjustment to the long run.

Table 9: Long run analysis: 
Udo Ginikachi Cynthia, Nwezeaku Nathaniel Chinedum, Kanu Success Ikechi

Effects of Capital Market Development on the Economic Growth of Nigeria

\begin{tabular}{|c|c|c|c|c|}
\hline Variable & Coefficient & Std. Error & t-Statistic & Prob. \\
\hline LASI & -0.400706 & 0.073446 & -5.455787 & 0.0000 \\
\hline LMCAP & -0.020926 & 0.078980 & -0.264949 & 0.7933 \\
\hline LNCL & -0.006604 & 0.027902 & -0.236676 & 0.8149 \\
\hline LNLS & 0.498599 & 0.105797 & 4.712796 & 0.0001 \\
\hline $\mathrm{C}$ & 4.734656 & 0.124786 & 37.94205 & 0.0000 \\
\hline $\begin{aligned} E C= & \text { LRGDP }-(-0 . \\
& +4.7347)\end{aligned}$ & $-0.0209^{*} \mathrm{LN}$ & \multicolumn{3}{|c|}{$-0.0066^{\star} \mathrm{LNCL}+0.4986^{\star} \mathrm{LNLS}$} \\
\hline
\end{tabular}

Source: E-views statistical output version 10

From the long run equation of the ARDL Error correction form, the coefficient of the constant term $(C)$ is 4.73 and it is positive. This shows that when other explanatory variables are held constant, LRGDP will increase by is 4.73 units.

The coefficient of LMCAP is -0.020926 and shows a negative relationship with LRGDP. This shows that a unit increase in LMCAP will lead to a decrease in LRGDP by 0.02 units. However, it is insignificant at $5 \%$ level of significance.

The coefficient of LASI is -0.400706 and shows a negative relationship with LRGDP. This implies that a unit increase in LASI will lead to a decline in LRGDP by 0.40 units. It is significant at $5 \%$ level of significance.

The coefficient of LNLS is 0.498599 and shows a positive relationship with LRGDP. This implies that a unit increase in LNLS will lead to an increase in LRGDP by 0.499 units. It is significant at $5 \%$ level of significance

The coefficient of LNCL is -0.006604 and shows a negative relationship with LRGDP. This implies that a unit increase in LNCL will lead to a decline in LRGDP by 0.006603 units. However, it is insignificant at $5 \%$ level of significance.

\subsection{Test of Hypothesis}

$\mathbf{H}_{\mathbf{o}}$ : LASI has no significant relationship with economic growth in Nigeria at $a=0.05$

Decision rule: Since the probability value of $(0.0001)$ is less than 0.05 the null hypothesis is rejected and it is concluded that all share index has a significant relationship with economic growth of Nigeria at $a=0.05$

\section{Test of Significance of LMCAP.}

$\mathbf{H}_{\mathbf{o}}$ : LMCAP has no significant relationship with economic growth in Nigeria.

Decision rule: since the prob .value $(0.3020)>0.05$, the null hypothesis is accepted and it is concluded that market capitalization has no significant relationship with economic growth of Nigeria at $a=0.05$

\section{Test of Significance of LNLS}

$\mathbf{H}_{\mathbf{o}}$ : LNLS has no significant relationship with economic growth in Nigeria.

Decision: Since the prob.value $(0.0000)<0.05$ the null hypothesis is rejected and it is concluded that the number of listed securities has a significant relationship with economic growth of Nigeria at $a=0.05$

\section{Test of Significance.}

$\mathbf{H}_{\text {o: }} \mathbf{L N C L}$ has no significant relationship with economic growth in Nigeria at

Decision: Since the prob.value $(0.0015)<0.05$ the null hypothesis is rejected and it is concluded that number of companies listed has no significant relationship with economic growth of Nigeria at $a=0.05$.

\subsection{Joint Test of Significance (ANOVA)}

From the ARDL long run form and bounds test, the F-prob value is 0.00000 which is less than 0.05 ; hence we reject the null hypothesis and conclude that there is a joint impact of all the explanatory variables (LMCAP, LASI, LNLS and LNCL) on LRGDP at 5\% level of significance. 
4.4 Goodness of Fit of the Model.

From the result of the regression, the Adjusted R-squared shows that about $67.3 \%$ variation in economic growth can be explained by capital market development variables. This means the model has a strong explanatory power in relation to economic growth in Nigeria.

4.5: Stability of the Model Via CUSUM

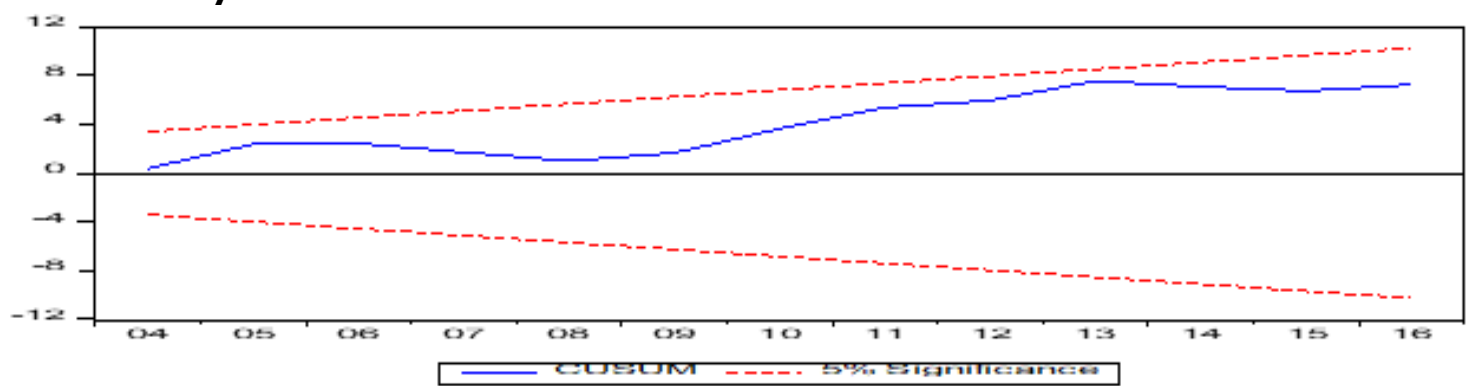

From the figure above, the cusum of squares line lies within the $5 \%$ bands; hence the model is stable at $5 \%$ level of significance.

4.6: Stability of the Model Via CUSUM of Squares.

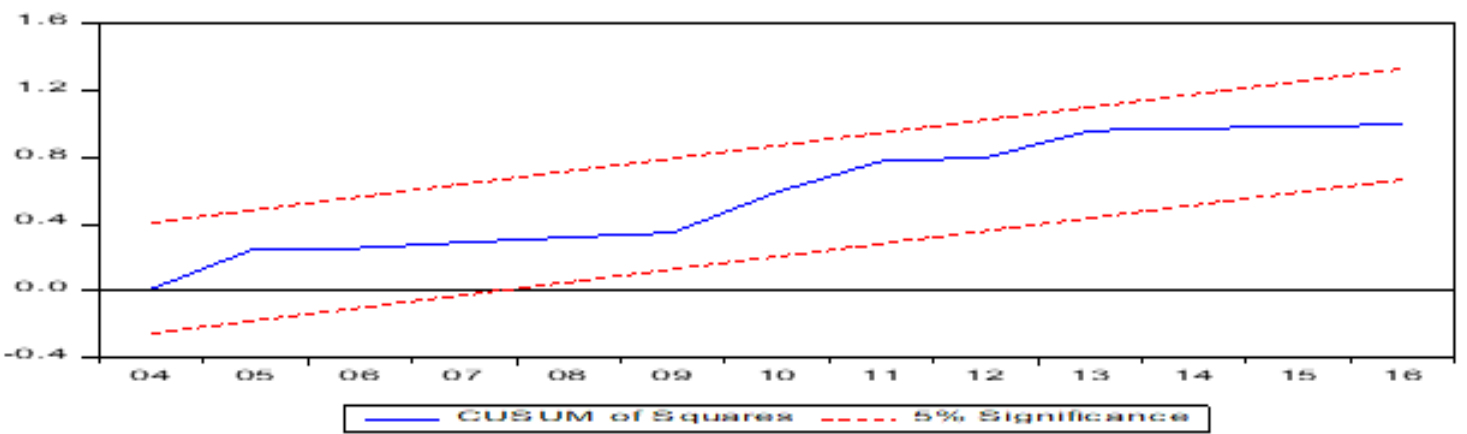

From the result above, the CUSUM of squares line lies within the $5 \%$ bands; hence the model is stable at $5 \%$ level of significance.

\subsection{Discussion of Findings.}

This research on the "Effect of capital market development on economic growth of Nigeria" revealed some important findings which are discussed below:

I. LMCAP: The coefficient is -0.020926 and does not conform to our a priori expectation. This suggests that market capitalization has a negative effect on economic growth of Nigeria. It was statistically insignificant at $5 \%$ level of significance which shows that market capitalization has no significant impact on economic growth of Nigeria as a necessary conclusion. This means that market capitalization cannot be used as a veritable instrument to increase the rate of economic growth of a country like Nigeria.

II. LASI: the coefficient of all share indexes is -0.400706 and does not conform to our a priori expectation. This shows that all share indexes has a negative relationship with economic growth of Nigeria. However, it was found to be statistically significant at $5 \%$ level of significance, which shows that All share index significantly affects economic growth of Nigeria in the long run. This finding is attributed to two main factors in the Nigerian economy. Firstly, the Nigerian investing populace is gradually turning to investment opportunities in the economy as a result of the rising confidence in the financial market; hence, they are more open to risk, rather being risk aversive to take advantage of activities in the stock market to make good of their investments. Secondly, the greater the activity in the stock market arising from the large volume of stock changing hands, the greater the buy/sell transactions and more positive performance of the economy in the long run.

III. LNLS: The coefficient of Number of listed securities is 0.498599and has a positive relationship with economic growth of Nigeria. The coefficient sign conforms to our a priori expectation. The test of hypothesis showed it has a significant relationship with economic growth; hence implying that it significantly contributes to economic growth of Nigeria in the long run. The result is surprisingly significant owing to the fact that Nigerian economy; 
a predominantly mono-product one was underdeveloped in the financial sector, with emphasis on the money and capital market..

IV. LNCL: The coefficient of Number of companies listed is-0.006604and has a negative relationship with economic growth of Nigeria. The coefficient sign does not conform to our a priori expectation and it is evidenced by the low magnitude of the coefficient. As expected, the test of hypothesis showed it has an insignificant relationship with economic growth; hence implying that it insignificantly contributes to economic growth in the long run.

From the foregoing discussions, it can be clearly seen that the growth of the Nigerian economy from the perspective of the capital market development stressed that All share index and Number of listed securities are the most influencing and potent factors that spur economic growth. In assessing the model, its stability was ascertained through the CUSUM and CUSUM of SQUARES test and it was found to be stable at $5 \%$ level of significance. The overall goodness of fit of the model was validated through the adjusted R-squared which showed a $99.1 \%$ explanatory power of the model

\subsection{Conclusion}

This study utilized an Auto Regressive Distributed Lag Model (ARDL) to investigate the Effect of Capital market development on economic growth of Nigeria: 1983-2016. The study revealed that All share index and Number of listed securities are the influencing variables that lead to economic growth of Nigeria at $5 \%$ level of significance in the long run; hence the long run results can be used to predict the effect of Capital market development on economic growth of Nigeria in the long run with a speed of adjustment of $73 \%$ annually. The adjusted R-squared of $67.3 \%$ shows a good fit of the model. It is therefore concluded that the All share index and Number of listed securities have significant impact on economic growth of the Nigerian economy in the long run. Although some of the results obtained were anticipated from a prori expectations and some not conforming to our expectations as a result of observed negative relationships with the dependent variable; there is need to proffer some policy recommendations which when implemented will lead to mitigation of such occurrences.

\subsection{Recommendations}

Based on the outcome of study, the following are recommendations are hereby made:

1)Government should remove impediments to stock market development in the form of tax, legal and regulatory barriers because they act as disincentives to investment in the capital market which has negative effects on most companies' market capitalization.

2) There is need to increase the number of listed companies in the Nigerian capital market. Government should find ways and means of boosting the confidence of investors to retain their portfolio investment. This can be done by putting in place regulatory laws that protect the investor and this will no doubt encourage him/her to keep investing in areas that yield maximum returns without fear of losing investible funds. If this is sustained, the number of listed securities and All share index of the capital market will without a doubt increase and invariably bring about a positive index in economic growth of Nigeria.

3) Lastly, there is also the need for policy consistency in the pursuit of growth of the Nigerian capital market. By being objective in this regard, counter developmental policies would not be allowed in to crowd out the gains of capital market development on economic growth in the long run.

\section{References}

- Abu, N. (2009). Does stock market development raise economic growth? Evidence from Nigeria. Journal of Banking and finance. 1(1)15-26.

- Adekunle, J. K. (2016). Anticipated change in the Nigerian Capital Market and its implication on Economic growth. International journal of African and Asian Studies, 22, ISSN2409-6938.

- Adekunle, O. A., Alalade, Y.S.A., \& Okulenu, S. A. (2016). Macro-Economic Variables and Its Impact on Nigerian Capital Market Growth. International Journal of Economics and Business Management. 2, 2, 22-37.

- Aderibigbe, J.O. (2004). Overview of the Nigerian Financial System.CBN Bullion, Lagos, 28, $1,5-9$. 
- Adeusi, S. O., Sulaiman, L. A. \& Azeez, B. A. (2013). Impact of Capital Market Development on the Nigerian Economy: A Post-SAP Analysis. Journal of Economics and Behavioral Studies. 5, 1, 1-7. CrossRef

- Adeyemi, K. S. (1998).Option for Effective Development of Nigerian Capital Market, at a Seminar Organized by Nigerian Economic Society at the Institute of International AFFAIRS Lagos $21^{\text {st }}$ January.

- Akingunola, R.O, Adekunle .O.A, \& Ojodu, H. (2012). Impact of Interest Rate on Capital Market: A case of Nigeria. Universal Journal of Management and Social Sciences, 2(11).

- Akinlo, A. E. \& Odusola, A.F. (2000). An Alternative Framework for Assessing the Impact of Nigerian Naira Depreciation on Output and Inflation. Kano:AERC Publication.

- Alile, H. I. \& Anao, R. A. (1986). The Nigerian Stock Market in Operation. Lagos: Jeromelaiho and Associate Limited.

- Anyanwu, J. C. (1996). Monetary Economics: Theory, Policy and Institutions. Lagos: Hybrid publishers limited.

- Araoye, F., Ajayi, E., \& Aruwaji, A. (2018). The impact of stock market development on economic growth in Nigeria. Journal of Business and African Economy. 4(1), 2545-5281.

- Ariwa, A., Onyele, I. \& Odili, S. (2016). The Impact of Stock Market Earnings on Nigerian Per Capita Income. African Journal of Accounting, Economics, Finance and Banking Research, 5(5): 77-89.

- Ariyo, A. \& Adelegan, O. (2005).Assessing the impact of capital market reforms in Nigeria: An incremental approach. A paper presented at the $46^{\text {th }}$ annual conference of the Nigeria Economic Society in Lagos in August.

- Atoyebi, K., Ishola, S. A., Kadiri, K. I.,Adekunjo, F. O. \& Ogundeji, M. O.(2013). Capital market and economic growth in Nigeria. An empirical analysis. Journal of Humanities and Social Sciences, 6(6): 60-68. CrossRef

- Bangladesh, M. d and Jianguo, G. (2018). Stock Market Development and Economic Growth: Preliminary Evidence from African Countries. Web Document. Journal of sustainable Development in Africa, (3), 1.48-56

- Donwa, P. \& Odia, J. (2010). An Empirical Analysis of the Impact of the Nigerian Capital Market on Her Socio-economic Development. Journal of Social Sciences. 24,(2) 135-142. CrossRef

- Donwa, P. \& Odia, J. (2010). An empirical analysis of the impact of the Nigerian capital market on her socio-economic development, Journal of Social Sciences, 24(2): 135-142. CrossRef

- Ekundayo, I. K.(2002). Creating a conducive Environment for Investment in the Nigerian Capital Market. Paper Presented at Public Enlightenment on Opportunities in the Capital Market for industrial Development of Kogi state Lokoja 29th March to1st April, 2002.

- Emeh ,Y. (2014)."Appraisals of Capital Market Efficiency on Economic Growth in Nigeria," International journal of business and management, December. 219-225.

- Enekwe, C. I., Agu, C. I., \& Eziedo, K.N. (2014). The effect of financial leverage on financial performance: evidence of quoted pharmaceutical companies in Nigeria. IOSR Journal of Economics and Finance (IOSR-JEF) e-ISSN: 2321-5933, p-ISSN: 2321-5925.5(3). CrossRef

- Esosa, B. D. (2007). Capital Market African and Global. The Book House Compare.

- Ewah, N. et al, (2009). Stock Market, Corporate Finance and Economic Growth: An Overview. The World Bank Review 10 (2), 223- 225. CrossRef

- Ewah, S. O. E., Esang, A. E. \& Bassey, J.U. (2009). Appraisal of capital market efficiency on economic growth in Nigeria. International Journal of Business and Management, 219-225. CrossRef

- Ezeoha, A., Ebele, O.\& Ndi, O. O. (2009). Stock Market Development and Private Investment Growth in Nigeria. Journal of Sustainable Development in Africa,11, (2).

- Gabriel, P. (2002). Stock Market Development and Nigeria's Economic Growth. Journal of Economics and Allied Fields, 2 (2), 116-132.

- Grace, O. A., Kofi, K.\& Robert, B. P. (2016). Investigating Nexus between stock exchange and economic growth in Ghana, British Journal of Economic, Finance and management science. 11(1).

- Ibru, G. M. (2000). Breaking New Grounds Reflection on the Nigeria Capital. Niger: Ibru Concepts.

- Kolapo, F. T. \& Adaramola, A. O. (2012). The impact of the Nigerian capital market on economic growth (1990 - 2010). International Journal of Developing Societies, 1(1) 11 - 19. CrossRef

- Liliana, R. S. (2014). Towards Strong and Stable Capital Markets in Emerging Market Economies. Center for Global Development (CGD) Policy Paper. 42 1-8.

- Mbat, D. O. (2001). Financial Management. Domes Associates Publishers. Uyo, Nigeria First Edition. 
- Ndanusa, S. (2004). Journey of the Nigerian Securities and Exchange Commission, SEC News, (16).

- Ngerebo, A. T. A. \& Torbira, L. L. (2014). The Role of Capital Market Operations in Capital Formation. Journal of Finance and Investment Analysis. 3,(1) 21-33.

- Nwankwo, G. O. (1991). Money and capital market in Nigeria today". Lagos: University of Lagos Press.

- Nyong, M.O. (2000). Capital market development and long run economic growth: Theory, evidence and analysis. First Bank Review, pp. 13-380biakor, 2011

- Obamiro, J.K. (2005). Nigerian Economy: Growth and the Role of Stock Market. Journal of Economic and Financial Studies, 2, 23-35.

- Obiakor, R. T. (2011). Does ccapital mmarket development spur economic growth?A Look at Africa's largest economy. The International Journal of Social Sciences and Humanities Invention 3(7), $2397-2406$

- Odetayo, T. A. \& Sajuyigbe, A. S. (2012). Impact of Nigerian Capital Market on Economic Growth and Development. International Journal of Arts and Commerce. 1(5).

- Odhiambo, N. (2009). Stock market development and economic growth in South Africa: An ARDL-bounds testing approach, retrieved from http://www.wbicongro.com/2. Nicholas. pdf.

- Ogunleye, O. (2015), "Stock Market Development and Long-run Growth," World Bank Economic Review. 10(2). CrossRef

- Ohiomu, S. \& Enabulu, O. G. (2011). The Effect of Stock Market on Economic Growth in Nigeria. JORIND (9)1, ISSN 1596-8303. Retrieved from:www.transcampus.org/journals.

- Okaro, S. C. (2002). The Nigerian Accountant. The Official Journal of the Institution of Chartered Accountants of Nigeria, 35(2).

- Okereke, N. O. (2003). End of Clear Speech by Director-General of Nigeria's Stock Exchange, Lagos. Lagos: Princewill Prints.

- Okereke, O. N. (2000). Stock market financing options for public projects in Nigeria. The Nigerian Stock Exchange Fact Book.

- Okodua, H. \& Ewetan, O. O. (2013). Stock Market Performance and Sustainable Economic Growth in Nigeria: A Bounds Testing Co-integration Approach. Journal of Sustainable Development. 6(8). CrossRef

- Okoye, L.U., Modebe, N.J., Taiwo, J.N and Okorie, U.E (2016). Impact of Capital Market Development on the Growth of the Nigerian Economy. Research Journal of Financial Sustainability Reporting, 1(1).

- Okoye, V. O. \& Nwisienyi, K. J. (2013). "The capital market contributions towards economic growth and development; the Nigerian experience". Global Advanced Research Journal of Management and Business Studies. 2,(2).

- Okunlola, F.A. (2012). Capital Market and Economic Growth in a Developing Economy: The Nigerian Experience. Unpublished MBA Seminar Paper: University of Port Harcourt.

- Olowe, R.N., Oluwatoyin, A. \& Fagbeminiyi, T. (2010). Weak form Efficiency of the Nigerian Stock Market Further Evidence, African Development Review 11 (1) Black Well; African Development Bank. CrossRef

- Oluwatosin, E. O. Taiwo, A. \& Yusuf, S. A. (2013). Empirical Analysis of the Impact of Capital Market Efficiency on Economic Growth and Development in Nigeria. Journal of Academic Research in Economics and Management Sciences, 2 (6). CrossRef

- Osamwonyi, I. O. \& Kasimu, A. (2013). "Stock Market and Economic Growth in Ghana, Kenya and Nigeria". International Journal of Financial Research. 4,(2). CrossRef

- Osei, K.A.(2006). "Macroeconomic Factors and the Ghana Stock Market", The African Finance Journal, 8 (1).

- Osinubi, T.S \& Amaghionyeodiwe, L.A (2003). "Stock Market Development and Long run growth in Nigeria. Journal of African Business, 4(3). CrossRef

- Owolabi, A. \& Ajayi, N. O. (2013). "Econometrics Analysis of Impact of Capital Market on Economic Growth in Nigeria (1971-2010)". Asian Economic and Financial Review. 3,(1).

- Pat, D. \& James, O. (2010). An Empirical Analysis of the Impact of the Nigerian Capital Market on Her Socio-economic development. Journal of Social Science, 24 (2). CrossRef

- Roslow, W.W. (1960). The Process of Economic Growth $2^{\text {nd }}$ Edition. London: Oxford University Press.

- Sam, A. \& Salami, K. (2014). 'The effect of capital market development on economic growth in Ghana' European Scientific Journal. 10(7).

- Securities and Exchange Commission (2015). Capital Market Bulletin.

- Securities Exchange Commission (2008). Capital Market Bulletin, A Publication of Securities and Exchange Commission.

- Stock Market Fact Book (2000). Standard and Poor's. New York: McGraw- Hill Companies. 
Udo Ginikachi Cynthia, Nwezeaku Nathaniel Chinedum, Kanu Success Ikechi

Effects of Capital Market Development on the Economic Growth of Nigeria

- Sule, O. K., \& Momoh, O.C., 2009.The Impact of Stock Market Earnings on Nigeria per Capita Income. African Journal of Accounting, Economics, Finance and Banking Research, 5(5).

- Taiwo, J. N. (2016). Impact of Capital Market development on the Growth of the Nigeria Economy, Research journal of financial Sustainability Reporting, 1(1).

- Yadirichukwu, E \& Ogochukwu, O. J. (2014). Evaluation of the weak form of efficient market hypothesis: Empirical evidence from Nigeria. International Journal of Development and Sustainability.

- Yadirichukwu, E. \& Chigbu, E. E. (2014). The impact of capital market on economic growth: the Nigerian Perspective. International Journal of Development and Sustainability. CrossRef 